\title{
Erratum to: Current trends in the detection of peroxide-based explosives
}

\author{
Raychelle M. Burks • David S. Hage
}

Published online: 23 February 2010

(C) Springer-Verlag 2010

\section{Erratum to: Anal Bioanal Chem}

DOI 10.1007/s00216-009-2968-5

Following publication the authors found a mistake in Table 1 of this contribution. The corrected Table 1 is given below. org/10.1007/s00216-009-2968-5.

R. M. Burks $\cdot$ D. S. Hage $(\triangle)$

Department of Chemistry, University of Nebraska,

704 Hamilton Hall,

Lincoln, NE 68588-0304, USA

e-mail: dhage@unlserve.unl.edu 
Table 1 Key physical and chemical properties of triacetone triperoxide (TATP) and hexamethylene triperoxide diamine (HMTD)

\begin{tabular}{|c|c|c|}
\hline & TATP & HMTD \\
\hline Formula & $\mathrm{C}_{9} \mathrm{H}_{18} \mathrm{O}_{6}$ & $\mathrm{C}_{6} \mathrm{H}_{12} \mathrm{~N}_{2} \mathrm{O}_{6}$ \\
\hline Formula weight $(\mathrm{g} / \mathrm{mol})$ & 222.24 & 208.17 \\
\hline Melting point $\left({ }^{\circ} \mathrm{C}\right)$ & 96 & 148 \\
\hline Density $\left(\mathrm{g} \mathrm{mL}^{-1}\right)$ & 1.2 & 1.6 \\
\hline Vapor pressure $(\mathrm{Pa})$ & 7.87 & $\begin{array}{l}\text { Not determined, due to reduced thermal } \\
\text { stability and vapor phase decomposition }\end{array}$ \\
\hline $\begin{array}{c}\text { Enthalpy of } \\
\text { sublimation }\left(\mathrm{kJ} \mathrm{mol}^{-1}\right)\end{array}$ & 72.5 & 76.2 \\
\hline $\begin{array}{c}\text { Detonation } \\
\text { velocity }\left(\mathrm{km} \mathrm{s}^{-1}\right)\end{array}$ & 5.3 & 5.1 \\
\hline TNT equivalence & $88 \%$ & $60 \%$ \\
\hline TNT vapor pressure $(\mathrm{Pa})$ & $\begin{array}{c}0.0005\left(15^{\circ} \mathrm{C}\right) \\
0.00173\left(25^{\circ} \mathrm{C}\right)\end{array}$ & \\
\hline
\end{tabular}

The melting points, densities, detonation velocities, and trinitrotoluene (TNT) equivalence data were taken from Ref. [7]. TNT equivalence compares blast over pressure or impulse of the explosive of interest to a similar amount of TNT. Data for the TATP and HMTD vapor pressures and enthalpies of sublimation were acquired from Ref. [76]. The TNT vapor pressure value is from Ref. [76].

Corrected citation for Ref. 76: Oxley JC, Smith JL, Lou W, Brady J, Propellants Explos Pyrotech, in press. 